\title{
Environmental Assessment of the UHE Tijuco Alto Hydropower Plant: the change of the dominant order
}

\author{
Amanda dos Santos Sousa \\ Paulo Santos de Almeida
}

${ }^{I}$ Escolas de Artes, Ciências e Humanidades/Universidade de São Paulo (EACH/USP), São Paulo, SP, Brasil.

II Escolas de Artes, Ciências e Humanidades/Universidade de São Paulo (EACH/USP), São Paulo, SP, Brasil.

\begin{abstract}
This research aims to identify, through the Strategic Field of Action Theory, the rationalities encompassed in the environmental assessment of the UHE Tijuco Alto Hydropower Plant (Ribeira River Watershed, Brazil) and to characterize the strategies of the stakeholders in the decision-making process. An interpretative description based on documents and content analysis of the environmental assessment process was adopted as our research method. The evaluation of such documents demonstrates that the strategic actions designed by the skilled actor - in this case, the Vale do Ribeira Movement of People Threatened by Dams - was fundamental to unveil the rationality shared by local communities. This fact has changed the dominant order, which prioritizes the logic of development and often results in the release of projects that affect or violate human rights.
\end{abstract}

Keywords: Social Participation; Social Skill; Environmental Impact Assessment; Environmental Law; Water Resources Governance.

São Paulo. Vol. 24, 2021

Original Article

DOI: http://dx.doi.org/10.1590/1809-4422asoc20200162r3vu2021L5AO 


\section{Introduction}

The multiple uses of water resources in Brazil have been guaranteed and regulated by Act No. 9433 since January 1997, and water should be used to ensure all activities, prioritizing human and animal direct consumption, especially during droughts (BRAZIL, p1997). However, experience has shown that the implementation of Hydropower Plants (HPP) is marked by conflict among actors who defend the use of the water to generate electricity and those interested in other uses (GALVÃO; BERMANN, 2015).

Those conflicts are triggered in the environmental assessment when the project is analyzed in its environmental feasibility (PIAGENTINI; BENASSI; PENTEADO, 2014). The question arisen in the debates is the imposed developmentalist logic, which prioritizes the commodification of natural resources and disregards the rationalities shared among local actors, whose visions, values, and discourses are shaped by the social place from which they speak (ZHOURI, 2018).

Into this controversy, the most common outcome is the predominance of the development discourse, which defends hydroelectric use in energy production as the best alternative for the use of water. The main argument has addressed the form of the use of the resource that increases the national supply of energy. Moreover, this use allegedly could also favor the quality of life of the local population, due to the generation of taxes, financial compensation, job creation, and the transfer of revenues (PULICE; MORETTO, 2017; PULICE et al., 2019). However, such effects are not directly linked to the idea of development in the affected sites. The cases in which positive changes have been observed are more associated with local management structures than with the simple increase in revenues (PULICE et al., 2019).

In that context, social participation has been a fundamental mechanism for reducing distributional problems arisen from water use because it gathers different rationalities in the decision-making process. Thus, this article has analyzed the emblematic case of the environmental assessment of the UHE Tijuco Alto, whose license request was denied on the grounds of intense participation of the society contrary to the project. The objective of the research is to identify, through the Theory of Strategic Fields of Action, the rationalities involved in the process and characterize the strategies of the main actors involved in decision making.

\section{Method}

We have adopted the interpretative description as methodology, which was obtained from documentary and content analysis (BARDIN, 1977) about the Brazilian environmental assessment process of the UHE Tijuco Alto (2004-2017). 


\section{Study area}

Vale do Ribeira (Ribeira Valley region) is located between the Brazilian states of São Paulo and Paraná and includes an area of a rich cultural and environmental importance for this region. The 25 municipalities that make up the territory are covered by $60 \%$ of Rainforest (Mata Atlântica), the largest continuous area in the country of this type of forest (GALVANESE; FAVARETO, 2014). Part of that environmental heritage is distributed in 14 preservation areas called Conservation Units (UC), which have been made up since 2008, as the" Mosaico UC Jacupiranga". Moreover, a large part of its 450,000 inhabitants (IBGE, 2019) is composed of traditional communities. Meanwhile, that diversity does not reflect in a better quality of life for its inhabitants. Historically, Vale do Ribeira has served as a supplier of natural resources at a reduced cost, becoming the region with the worst socioeconomic indicators in the state of São Paulo (GALVANESE; FAVARETO, 2014; MIRANDA; GOMES, 2016).

The UHE Tijuco Alto was planned to be implanted in this region as a dam to be installed on the river of Ribeira de Iguape, which corresponds to the greatest share of the watershed in the area and the only one not yet dammed in the State of São Paulo (Figure 1). The installation of the plant would be located exactly $11 \mathrm{~km}$ above the city of Ribeira (state of São Paulo) and it would reach the lands of its municipality and also the area of Adrianópolis (state of Paraná) (CBA, 2005).

Figure 1 - Location of the study area

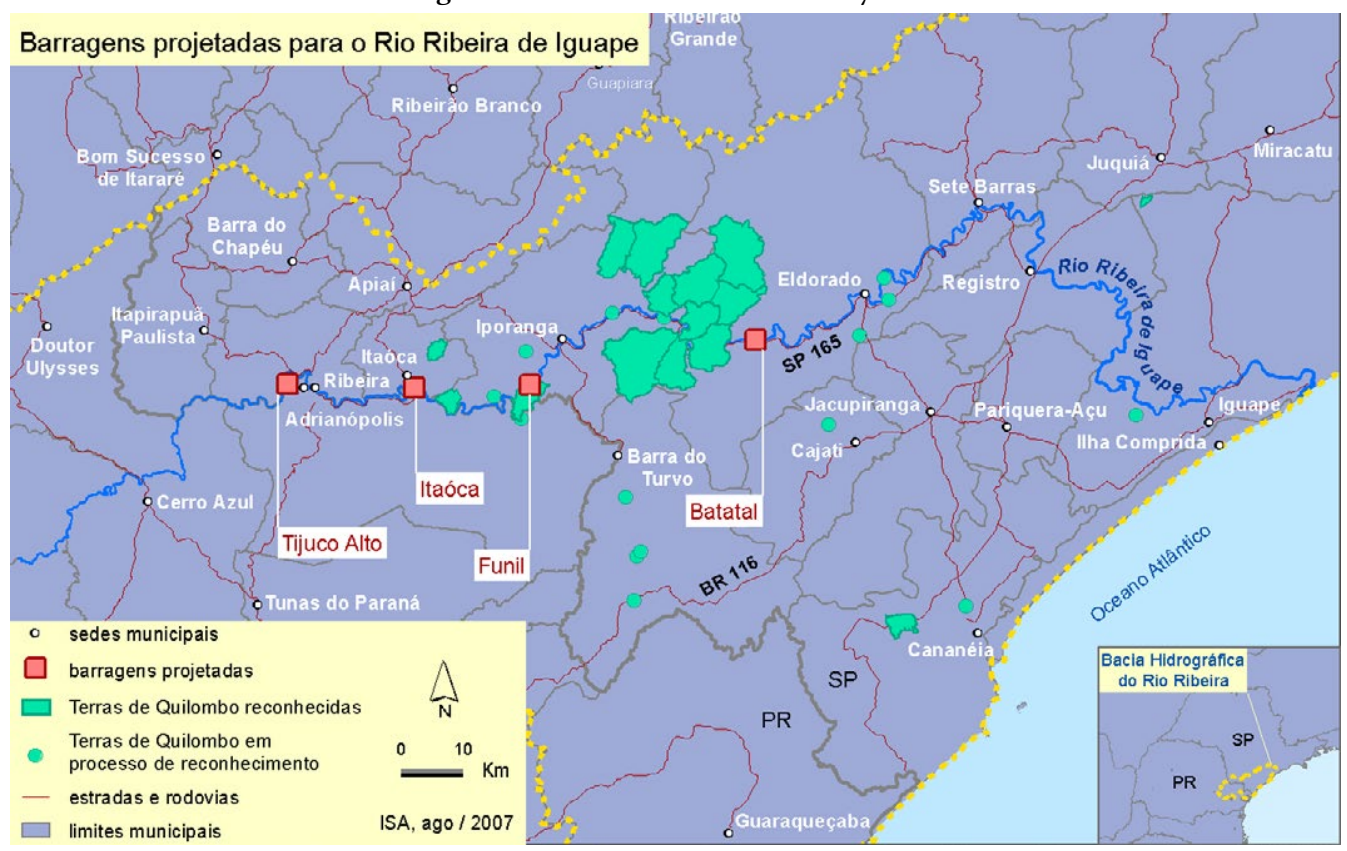

Source: Instituto Socioambiental (ISA), 2007, p. 301.

The installation of the UHE Tijuco Alto forecasted the generation of 120,000 to 
$150,000 \mathrm{~kW}$, sufficient to supply between 564 to 705 thousand people. However, as a strategy for energy self-sufficiency, the generation would be entirely for private use by a single local company (GALVANESE; FAVARETO, 2014).

\section{Data collection procedures}

Os dados foram coletados em julho de 2018, no processo de licenciamento ambiental disponibilizado pelo Instituto Brasileiro de Meio Ambiente (IBAMA), composto por 30 volumes, com início em julho de 2004 e encerramento em maio de 2017.

\section{Theoretical approach used for data analysis}

Over the past few years, as a counterpoint to Neoclassical Economics, different economic strands have incorporated the environmental issue into their explanatory models, due to evidence about the pressure exerted on natural resources. Among the competing models, Ostrom and Pigou attribute to the State a relevant role in solving the dilemma of open access goods exhaustion and promotion of allocative justice (OLIVEIRA et al., 2020). Therefore, institutions have the role of stimulating actors to cooperate in the use of shared resources in order to avoid their exhaustion and provide alternatives for a less predatory development (GALVANESE; FAVARETO, 2014).

Sociologists attribute to institutions an enduring character that defies the change of their status quo, which implies in admitting that capitalism always wins, the state trumps the non-state and social movements are doomed to fail. On the other hand, Fligstein and McAdam introduce the Theory of Strategic Fields of Action (FLIGSTEIN; MCADAM, 2012), which states that institutions are "formal norms and rules collectively conceived, responsible for stabilizing the relationships between agents of a given social field, which guide agents in their strategic social action" (PAVANELLI; IGARI, 2019, p. 253).

The Theory of Strategic Fields of Action aims to explain how social change and stability are rooted in social life and permeated by a complex web of Fields of Strategic Actions, in which the skilled actor and the crises play the main role in the institutional order. Note that the field as an analytical category appears in various sociological approaches (Table 1). Each theory uses the concept according to its specificities, but the focus is on the relational/structural and symbolic dimension. This is associated with the communicative space among different social actors: as a result of the relational configuration among them, the dimension is responsible for delimiting values, social norms, sanctions, and other aspects in a more interactive and reciprocal perspective of the institutionalization process (MACHADO-DA-SILVA; GUARIDO FILHO; ROSSONI, 2006). 
Table 1 - Theoretical Perspectives on Fields

\begin{tabular}{|l|l|l|}
\hline $\begin{array}{l}\text { Theoretical } \\
\text { Perspective }\end{array}$ & Authors & Description \\
\hline $\begin{array}{l}\text { Field as the totality } \\
\text { of relevant actors } \\
\text { gio; } \\
\text { Powell } \\
(1983)^{1}\end{array}$ & $\begin{array}{l}\text { Di Mag- } \\
\text { and interact more often among themselves than with ac- } \\
\text { tors from outside the field, thus constituting a recognized } \\
\text { area of institutional life. }\end{array}$ \\
\hline $\begin{array}{l}\text { Field as a structured } \\
\text { space of positions in } \\
\text { dispute }\end{array}$ & $\begin{array}{l}\text { Pierre } \\
\text { Bourdieu } \\
(1984)^{2}\end{array}$ & $\begin{array}{l}\text { Structured space of positions where dominant and domi- } \\
\text { nated fight for the maintenance and attainment of certain } \\
\text { positions. The camps are arenas in which struggles are } \\
\text { fought for the conquest of positions and capital. }\end{array}$ \\
\hline $\begin{array}{l}\text { Field as } \\
\text { Institutional sphere } \\
\text { of interest in } \\
\text { Dispute }\end{array}$ & $\begin{array}{l}\text { Fligstein } \\
\text { and } \\
\text { McAdam } \\
(2012)^{3}\end{array}$ & $\begin{array}{l}\text { Socially constructed arenas where actors with varied re- } \\
\text { sources seek advantages. They are the fundamental spaces } \\
\text { of operation of } \\
\text { the actors in individual and collective actions. The politi- } \\
\text { cal and organizational } \\
\text { life of society is structured by the distribution and ar- } \\
\text { ticulation of the different fields, which function as basic } \\
\text { unitary blocks in the construction of the social fabric. }\end{array}$ \\
\hline
\end{tabular}

There is a notion of field used by the authors as an analytical category that makes it possible to understand how institutions act in the dynamics of actors and, consequently, how they corroborate the maintenance of the status quo. This is the perspective adopted on this research as it was for Fligstein and McAdam (2012): it gathers, in a single thesis, the discussions on origin, maintenance and transformation of a field, through the investigation of the dynamics of stability and change in its interior (CANDIDO et al., 2018).

In that approach, the Fields of Strategic Action (Figure 2) are social spaces with rules (formal and informal), specific objectives, internal hierarchy of power and interpretive framework, aspects have shared and legitimized by all actors of the field (GODOY, 2011; FLIGSTEIN; MCADAM, 2012). It is the recursive relationship between the institutional framework in force and the balance of power among the actors that makes institutions emerge (PAVANELLI; IGARI, 2019). 


\section{Figure 2 - Composition of a Strategic Field of Action}

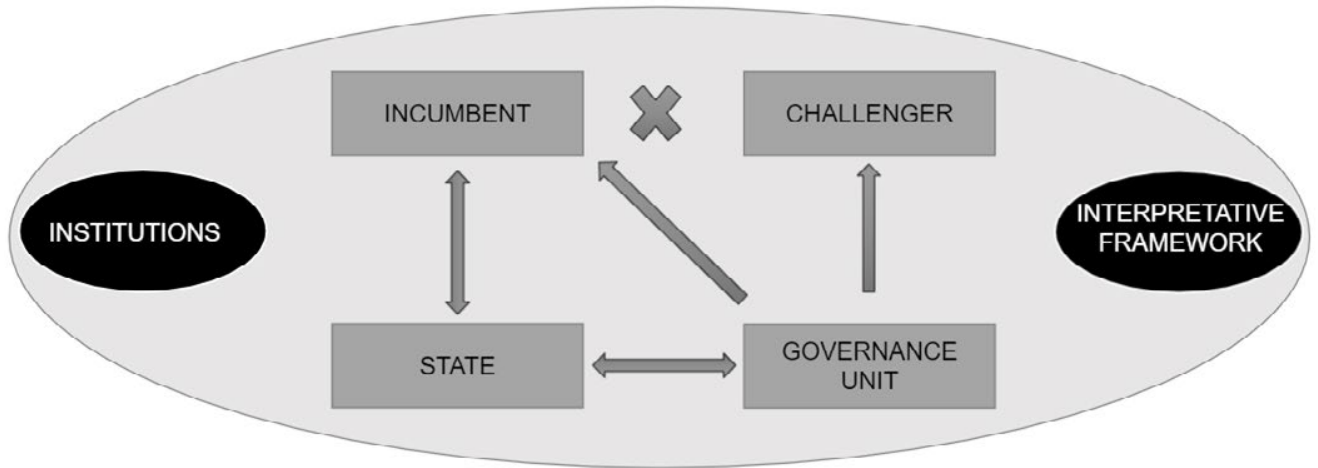

Source: by authors.

The dynamics within the field takes place with the coalition of actors fighting for their interests. In this relationship, the dominant actors are those whose interests and visions tend to be strongly reflected in the prevailing organization of the Fields of Strategic Action; therefore, they exert a disproportionate influence. Those actors consolidate institutions that stabilize the relationship in the field, favoring the existing coalitions (PAVANELLI; IGARI, 2019).

On the other hand, the challengers occupy less privileged spaces and exert little influence on the operation on the field. The governance units are in charge of supervising the compliance of actions with the rules, and - in general - facilitate the good functioning and reproduction of the system. However, this oversight cannot be confused with neutrality: it should be seen as a mechanism that reinforces the influential perspective and protects the interests of the incumbent (FLIGSTEIN; MCADAM, 2012).

In that specific building, there is also the State being the actor with the greatest potential to shape the prospects for change and stability in practically all the fields. This is due to the fact that the institution exercises territorial sovereignty: it transforms the agreements resulting from confrontations into legal rules or actions to be implemented. However, although the State exerts coercive force on other actors, its stability depends, at least in part, on the support of actors who control the non-state fields, i.e., the so-called incumbent ones (FLIGSTEIN; MCADAM, 2012).

Within the field of conflict, skilled actors have a strategic role: they are the ones who contribute to changing or maintaining institutions through common discourses of interest and identity, which are highlighted in times of crisis. The social skill that makes those actors relevant is defined as the highly developed cognitive capacity to interpret people and environments, to frame courses of action and to mobilize people to serve broader conceptions of the world and themselves (FLIGSTEIN, 2001).

Those types of actors are able to be positioned in coalitions both to maintain the stability of the field, through the conservation of the current order, and to disturb the 
balance and promote institutional change (PAVANELLI; IGARI, 2019). The potential of changes increases in times of crisis when the current institutions lose the role of ensuring the predictability of actions and give room for divergent actors to present another alternative. Those instabilities could be internal or external (more common) to the field (PAVANELLI; IGARI, 2019).

Due to more complete analysis of the entire context that involves a specific field and its relationship with the others, the Theory of Strategic Fields of Action has been chosen to support the documentary and content analysis of the Environmental assessment of the UHE Tijuco Alto, from the following analytical categories: incumbent and challengers actors, Governance Units, State and Field of Strategic Action.

\section{Results and discussion}

\section{History of Environmental Assessment of the UHE Tijuco Alto - Building of the field}

During the 1980s, ELETROBRÁS (Brazilian Electric Utility Holding Company) prepared the hydropower inventory that foresaw the building of four HPPs along the Ribeira de Iguape River, in Vale do Ribeira: Tijuco Alto, Funil, Itaoca and Batatal. In addition to increasing power generation, the project had the purpose of flood control in the region (ROUGEMONT; GOMÉZ, 2011).

In 1988, CBA (Brazilian Company of Aluminum) acquired the right to exploit the hydraulic energy potential of Tijuco Alto. The plan included the municipalities of Cerro Azul (state of Paraná), Adrianópolis (state of Paraná) and Ribeira (state of São Paulo) and was based on the concession granted by the Decree No. 96746 of October 21, 1988, which provided for a 30-year period of concession (BRASIL, 1988).

Following that year, CBA initiated the environmental assessment in the states of São Paulo - in the State Secretariat of Environment (SEMA) - and also in the state of Paraná - in the Environmental Institute of Paraná (IAP). Until then, the decisions on the process were made by the initiatives of the Office of the Chief of Staff, ELETROBRÁS and CBA (JERONYMO; BERMANN; GUERRA, 2012). Thus, the action was configured as a stable Field of Strategic Action predominantly maintained by following the formal rules of environmental licensing.

The beginning of environmental assessment has triggered the conflict between the local community and the entrepreneur. The lack of knowledge of the project, associated with the rumors that the central square of Cerro Azul (state of Paraná) would be flooded, and the municipality would be divided in two, led the local population to panic (LEMOS, 2005) because the field showed signs of crisis: by instilling in society a feeling of insecurity, the institutions associated with the environmental assessment protocols lost their role of ensuring predictability and stability. As highlighted by Fligstein and McAdam (2012), in those moments three situations are predicted: i) the state tends, initially, to bet on the return to the status quo, aiming to stabilize the field; ii) the challengers engage in some 
innovative action, aiming to advance in their position; or iii) new groups emerge.

In that case, two groups of challengers emerged: the Mobilization Committee of Vale do Ribeira and the Movement of People Threatened by Dams (MOAB). The two organizations began to act against the enterprise, claiming that the supposed social benefits of the building did not justify the damage that could be caused to the environment and the local population (LEMOS, 2005). Therefore, the groups were constituted as the main challengers actors in the field.

Over time, MOAB has taken the lead. In the public hearing held in May 1994, which lasted 13 hours, the group drew media attention to the negative impacts of the project, in a mobilization under the slogan "Land yes, dam no." However, even with the great public commotion against the enterprise, SEMA (Secretariat for Infrastructure and Environment, state of São Paulo) and IAP (Environmental Institute of Paraná) granted the preliminary license to CBA (JERONYMO; BERMANN; GUERRA, 2012).

Despite this, the social movements, supported by the legislation and led by MOAB, initiated a public civil action 1 that unfolded into a lawsuit by the Federal Public Ministry (MPF). The result was the suspension of the preliminary license, considered improper, on the grounds of the interstate character of the enterprise. Thus, in 1997, CBA filed a new environmental assessment process with IBAMA by submitting the same EIA/RIMA (Environmental Assessment Report) of 1994.

Among the opening of the environmental assessment process (1997) and the holding of the public hearing (2003), MOAB developed various actions to engage and mobilize the population, with emphasis on the actions carried out in the city of São Paulo (state of São Paulo): in 2001, there was a demonstration at the headquarters of IBAMA (in the city of São Paulo) and, the following year, a walk downtown. In September 2003, CBA had its second application for environmental assessment denied, under the following justifications: out of date EIA/RIMA; superficial studies on fauna, flora and water contamination; and lack of integrated assessment (JERONYMO; BERMANN; GUERRA, 2012).

In 2004, when the field seemed stable, the National Council of Consulting Engineers (the contracted environmental consultancy to prepare Environmental Assessment Report) asked IBAMA for a joint field inspection to outline a new term of reference with the intention of being more assertive in the preparation of the new EIA/RIMA. It has been noted that in this arrangement, the establishment of a closer relationship with the environmental regulatory agency, stimulated by the environmental consultancy, presented itself as neutral within the process. That neutrality is as provided for in the law that creates the National Environmental Policy, which determines that the environmental impact evaluation (EIA) must be conducted by an independent team of the project proponent (BRASIL, 1981).

In response to those requests, IBAMA carried out an inspection of the area with the environmental consultancy and CBA in April 2004. That action is part of the internal rules of the field: it is usual for the environmental agency to carry out the technical visit in the area with the entrepreneur. However, the action was disapproved by the community that interpreted it as a biased relationship between those actors. The dissatisfaction 
was formalized in a document filed in the process, which demanded an answer from the environmental agency about what had happened.

At the time, MOAB had requested IBAMA to hold a prior public hearing with the communities, without the presence of CBA, to discuss the terms of reference. However, that document had already been issued and, as a suggestion, the environmental agency transferred the demand to the environmental consultancy. The latter tried to organize the meeting directly with $\mathrm{MOAB}$, which did not accept, and also filed a document pointing its dissatisfaction with the posture of IBAMA in delegating the responsibility to the entrepreneur. The meeting was subsequently held in Cerro Azul (state of Paraná) without MOAB participation.

During the process, the challengers remained active with MOAB filing several lawsuits expressing its opposition to the undertaking and the Socio-environmental Institute began to provide legal advice to the communities. Other 78 organizations requested from the General Secretariat of the Presidency of the Republic an integrated environmental evaluation of the four planned dams and the suspension of the environmental assessment of the UHE Tijuco Alto. In 2007, over one thousand people protested on BR-106 Road against the building of the UHE Tijuco Alto (INSTITUTO SOCIOAMBIENTAL, 2007).

On the side of the incumbent parties, the environmental consultancy firm carried out constant inspections in the territory with the presence of IBAMA, IAP, and SEMA; published positive news about the enterprise in local and national broadcasting and renewed environmental studies at the Ribeira de Iguape River Basin Committee. The petition in favor of the enterprise was also filed.

On 30 March of 2007, the report of the UHE Tijuco Alto EIA/RIMA was published on the Official Newspaper and the dates of the public hearings to be held in Cerro Azul (state of Paraná), Adrianópolis (state of Paraná), Ribeira (state of São Paulo) and Eldorado were announced and after that publication, the 45-day period for requesting a public hearing began (CONAMA, 1987). During that period, supplementary hearings were requested in the cities of Cananéia, Iguape, Registro and São Paulo, all cities in the state of São Paulo, and Curitiba, in Paraná. Among the requesting institutions were the Federal Public Ministry (MPF), and the Department of Justice of São Paulo (MPSP).

However, within the deadline, IBAMA maintained the hearings in the municipalities already disclosed, adding only one meeting in the municipality of Registro (state of São Paulo). The decision not to incorporate the other locations was supported by the responses of CBA and justified by the fact that the requests for holding public hearings in the cities of São Paulo and Curitiba lacked factual relevance or legal basis, since there was no connection in those locations with the impacts of the undertaking. Regarding Iguape or Cananéia, the questions could be answered in the municipality of Registro. The decision was endorsed by the General Attorney's Office and the Federal Attorney General's Office.

Given the above, even though the legislation guarantees the holding of a public hearing whenever requested by a civil entity, the Public Prosecution Department or 50 or more citizens (CONAMA, 1987), IBAMA rejected the requests. The decision, which 
initially reiterated the supremacy of the incumbent groups in the countryside, was an element present in countless moments of agitation during the hearings and a relevant factor in the analysis of decision-making on the feasibility of the undertaking. During that process, the field was constructed with the actors strategically positioned in favor of the defended rationalities. The mapping of the actors who have influenced the final process of environmental assessment during the public hearings is presented in the next section.

\section{Mapping the social actors and rationalities involved: composition of the field}

Twenty players were mapped out in the minutes of the five public hearings held in July of 2007: $40 \%$ constituted the incumbent group; 50\% the challengers, and 10\% the Governance Unit (Table 02).

Table 2 - Social actors, interpretative framework, and position in the Field of Strategic Action

\begin{tabular}{|c|c|c|}
\hline Actor & Field Position & $\begin{array}{l}\text { Interpretative } \\
\text { Framework }\end{array}$ \\
\hline 1- Companhia Brasileira de Alumínio - entrepreneur & \multirow{8}{*}{ Incumbent } & \multirow{8}{*}{ Developmentalis } \\
\hline $\begin{array}{l}\text { 2- National Consortium of Consulting Engineers - } \\
\text { environmental consulting }\end{array}$ & & \\
\hline 3- State Representative SP (A) & & \\
\hline 4- State Representative PR (A) & & \\
\hline 5- Mayor Cerro Azul & & \\
\hline 6- Mayor of Registro & & \\
\hline 7- Mayor of Dr. Ulysses & & \\
\hline 8- Adrianópolis City Council & & \\
\hline 9- Movement of People Threatened by Dams - MOAB & \multirow{10}{*}{ Challengers } & \multirow{10}{*}{ Symbolic } \\
\hline 10- Ivaporunduva Quilombola Community & & \\
\hline 11- Socio-environmental Institute - ISA & & \\
\hline $\begin{array}{l}\text { 12- Institute for Sustainable Development and Citi- } \\
\text { zenship of Vale do Ribeira (Ribeira Valley region) }\end{array}$ & & \\
\hline 13- SOS Mata Atlântica & & \\
\hline 14- Community of Cananéia & & \\
\hline 15- Unicamp Researcher & & \\
\hline 16- State Representative SP (B) & & \\
\hline 17- Mayor of Ribeira & & \\
\hline 18- Federal Public Ministry & & \\
\hline 19- Brazilian Institute of Environment & \multirow{2}{*}{$\begin{array}{l}\text { Governance } \\
\text { Unit }\end{array}$} & Technic \\
\hline 20- Ministry of Mines and Energy & & Developmentalist \\
\hline
\end{tabular}


Source: Prepared by the authors.

In Brazil, there is a clash of rationalities when considering the experiences of environmental assessment processes, especially with regard to HPPs. That conflict occurs because impacts are associated with dam construction: deforestation, loss of aquatic and terrestrial biodiversity, greenhouse gas emissions, relevant interruptions in the livelihoods of affected communities, and, above all, population displacement (ROQUETTI; MORETTO; PULICE, 2017; MORAN et al. , 2018; FEARNSIDE, 2019).

Hence, the affected communities fight for the right to remain in their territory, and they rely on the support of the academic community, digital networks, and Public Prosecution Department. This rationality was endorsed by organizations linked to the defense of Human Rights, and environmental conservation. On the other side, as support for the incumbent order, there is also the discourse reinforced by institutions that, in the name of social security, defend the need to expand the generation of electricity to avoid the risk of an energy shortage (HERNANDEZ, 2012).

From the above-mentioned analysis is observed: by one side, the challengers, who are against the implementation of the project, justify their position on behalf of the traditional uses shared on the land. An example is the speech of the state representative B. In the hearing held in the municipality of Registro (state of São Paulo), he highlighted aspects of the history and popular organization of the region and drew attention to the conflict between the social and economic interests of the project. In the end, he remembered the rights guaranteed by the Brazilian Federal Constitution to traditional communities: in case of disrespect, the case should be decided by the Brazilian Federal Supreme Court (STF).

On the other hand, in the group of the incumbent actors, the focus of the discourses is the economic factor, given that not even the energy produced has the objective of public use. The defense of the actors is divided into two groups: i) the first one is composed by CBA and Environmental Consultancy, in favor to energy autonomy and the expansion of business profit; ii) the second one, involves the other actors, who bet on the generation of taxes, which investments would be reverted towards the supposed development of the region, especially during the building of the dam.

Among those groups, IBAMA works as a Governance Unit, seeking to legitimize and naturalize the logic and rules of the field through the collection and provision of standardized information for all actors. Aligning the Brazilian Ministry of Mines and Energy, and that agency, it constitutes the public face of the field, working as well as the link between state and non-state. This function is characterized in the following excerpt taken from the minutes of the hearing held in the municipality of Registro (state of São Paulo): "the representative of IBAMA says that the public hearing is an important instrument for the assessment to take place and the administrative process to lead to the granting or denial of the preliminary license" (IBAMA, 2007, p. 2901).

However, it should be noted that, although the Governance Unit assumes an intermediary role, it cannot be understood to function as neutral. As pointed out by Fligstein 
and McAdam (2012), that space is generally developed with the objective of maintaining the status quo. However, in that case, it was not possible to affirm that IBAMA shares the rationality of the incumbent group. Therefore, it was associated with technical rationality, which is not neutral either.

$\mathrm{MOAB}$ and the environmental consultancy, as skilled actors, achieved the cooperation of other actors towards the objective of the groups to which they belonged. $\mathrm{MOAB}$, however, was the one that developed more innovative strategic actions, due to its belonging to the coalition that challenges the status quo. The activities of the group had as their main strategy to produce meaning for the other actors through the history of the territory, appealing to its identity. The environmental consultancy presented neutrality as a strategy, as whether it was only mediating the interests of the entrepreneur (incumbent) and the environmental quality (part of the agenda of the challengers).

It should be noted that, during the public hearings the formal structure of the meeting was questioned by the "Coletivo de Educadores de Lagamar" (challengers):

I would like to request the chairman of the table, that the entrepreneur has the same three minutes as the time given to the population to respond (...). CBA has 45 minutes to speak about the dam and the opposing parties do not. In this case, those affected by the enterprise should have the same 45 minutes to present their problems (IBAMA, 2007, p. 2631).

Most researchers blame the institutions for the lack of effectiveness of the public hearing, suggesting that the structure does not enable full social participation (ZHOURI, 2008). It was made only as a justification to confer legitimacy to decisions that, for the most part, have already been taken at an earlier time.

As an effect of this invisibility, the challenging group bet on strategic actions to draw attention to their demands and claims. In the first public hearing, a group wore black tunics and hoods in Cerro Azul (state of Paraná) simulating the symbolic burial of Vale do Ribeira which drew the attention of all people attending it. In the city of São Paulo, the demonstrations were even more intense. Even before starting the meeting in Eldorado, the members of MOAB were hindered by the local security team from fixing banners in the place. This generated protest during the public hearing, since there were pro-business banners installed at the site.

In an attempt to maintain the balance of the field, IBAMA invited the representative of the Ivaporunduva Quilombola Community to compose the table with other actors. The initiative also came as a response to repeated questioning made in previous hearings, which insinuated a predilection for the entrepreneur in facilitating rules that benefited their position. However, the representative considered it unethical and unfair to be invited to participate at the table, since it was a meeting to defend the enterprise. Therefore, after stating his displeasure, he left the meeting. That tense atmosphere was interrupted by the presentation of the project and restarted with the opening of the plenary, which required constant interventions by the chairman of the meeting. 
The last public hearing, held in Registro (state of São Paulo), was marked by numerous protests by the challengers, who had already won the right to occupy the table, even though they did not do so. The coalition had the majority support of the population, which feared experiencing the impacts systematically reported by the group. During this meeting, the public even moved over the meeting and it turned their backs on the state representative of the state of São Paulo. A, who had practically attended all the meetings, reinforced his position favorable to the enterprise. The challengers also expressed rejection of the speech of the mayor, who presented his fulfillment with the project. One of the participants once again questioned the close relationship among IBAMA, CBA, and with the environmental consultants, suggesting that it was a case of some kind of promiscuity and partiality in the process. Trying to clarify, the president of the table was the target of criticism from the participants.

\section{The change of the dominant order: the Environmental Permit Denied}

Once the public hearings stage was completed, the challengers presented a positive balance of participation. This occurred because the demonstrations drew the attention of the media, attracting several academics who contributed with independent studies on the implementation of the project in the region. Furthermore, the public hearings held were closely monitored by the Federal Public Ministry (MPF), which found in favor of the affected communities.

In 2007, the Public Prosecution Department of the state of São Paulo (MPSP) opened a Civil Inquiry to investigate the large-scale environmental damage in the region of the Complexo Lagunar due to the implementation of the project. In 2008, IBAMA issued a Technical Opinion concluding that the enterprise was feasible. However, it requested responses to pending legal requirements, such as holding a public hearing in the localities that were included in the area of influence of the project and which had been the subject of claims by local communities. After the issue of the Technical Opinion, IBAMA received opposition from some organizations: MPSP, MOAB, Instituto Socioambiental, Brazilian Speleological Society and National Forum of Civil Society in River Basin Committees.

In 2011, the MPF opened a specific Civil Inquiry with the objective of monitoring compliance with the decision handed down in the records of the class action process (ACP). At that stage, CBA was ordered not to start the works until the concession for the use of electric energy was granted by the National Department of Water and Electric Energy of the National Agency of Electric Energy (ANAEEL). During the evaluation period of the studies ( 9 years), all the actors remained in action, as there was a common feeling of uncertainty in the field (Figure 3). 
Figure 3 - Trajectory of innovative actions organized between the reopening of the Environmental Assessment and the beginning of public hearings

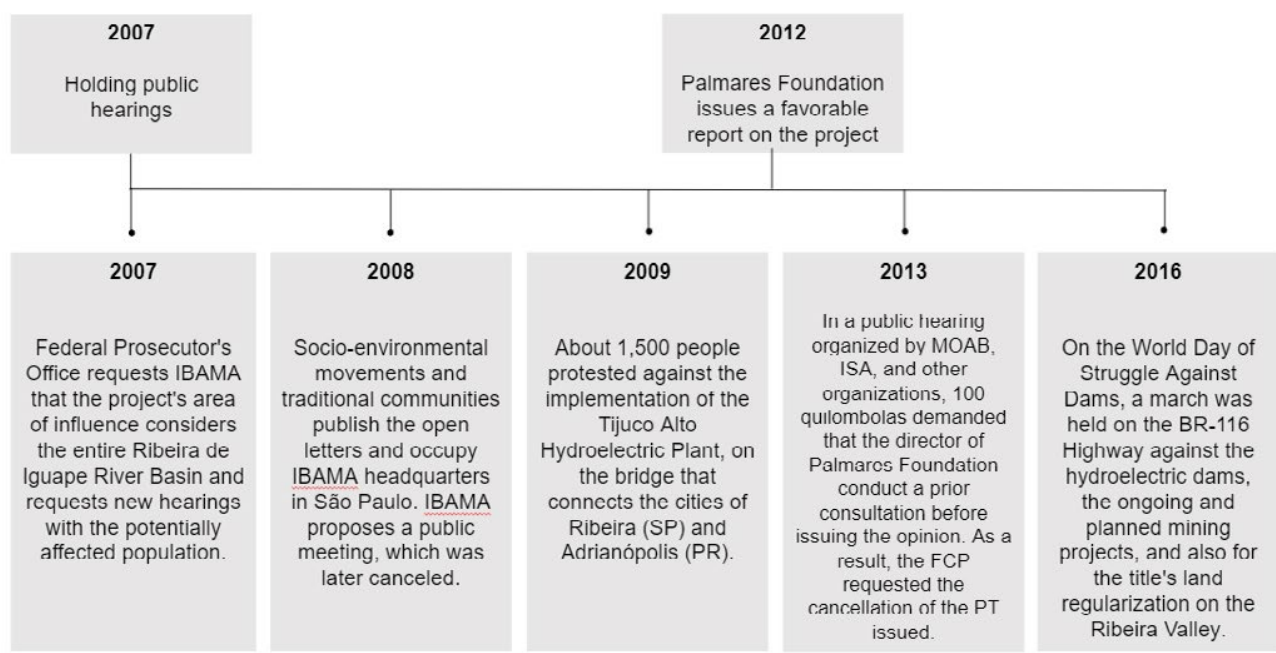

Source: Prepared by the authors, with information taken from the website of the Instituto Socioambiental (ISA).

In 2013, after a technical inspection, the IBAMA team analyzed the new documents attached to the process (ACP) and requested additional studies from the environmental consultancy firm to support a consistent analysis of the socio-environmental conditions of the project. In 2016, with the analysis completed, the General Coordination of Electricity Infrastructure understood it was not pertinent to continue the assessment, due to the high environmental sensitivity of the region and the outdated study. Thus, on 3 November of 2016, the Board of directors of the Environmental assessment dismissed the license, considering, in addition to environmental and economic issues, the strong popular pressure against the implementation of the project:

Furthermore, it is important to point out that the assessment process of the UHE Tijuco Alto received strong popular pressure against the implementation of the project, with dozens of notes of rejection of the project and recommendations from various social entities and the MP for the non-building of the project. Such manifestations mainly address the social and environmental relevance of the area potentially affected by the project, as well as the significant presence of traditional communities and quilombolas that would eventually be affected by the HPP (IBAMA, 2016, p. 5128).

In 2018, the Federal Court with jurisdiction in Itapeva (SP) declared extinct the concession for the exploitation of the electric energy potential of the UHE Tijuco Alto. In addition, that agency determined it was unfeasible to recompose or extend the term that appeared to grant and that it was impossible to adopt it as a grant of water resource rights by the National Water Agency. The decision was the result of a lawsuit that the 
MPF and MPSP filed in 2016 against CBA.

\section{Conclusion}

The legal structure of governance of Brazilian water resources, as well as the Environmental Assessment, ensures social participation in the process. In addition to the inclusion of different rationalities in the discussion about the project to be implemented, the environmental assessment enables the progressive negotiation of permits in order to ensure compliance with the requirements established in the release of the project (ZHOURI, 2018).

However, this legal framework has not been sufficient to ensure that decision making considers, with due equity, all the rationalities existing in the territory. A report prepared by the Council for the Defense of the Rights of the Human Person in 2010 confirmed that the current model for dam construction in Brazil led to serious Human Rights violations. The consequences of that process enhance existing social inequalities, resulting in situations of poverty and social, family and individual breakdown. Furthermore, people are deprived of their land, their histories, and their knowledge during the process of implementing such projects (JERONYMO; BERMANN; GUERRA, 2012).

The present dominant logic in the environmental assessment process is based on technical knowledge, and also the discussions that permeate a field tend to delegitimize the other competing rationalities (ZHOURI, 2018). However, it is an example of a process in which the development rationality competed with other rationalities shared in the territory and had the license application rejected.

Due to the unique nature of the case, the objective of this article was to identify the present rationalities in the field and to characterize the strategies of the main actors involved in the decision-making process, as pointed out by the Theory of Strategic Fields of Action. Analyzing the process history, it was possible to observe that the field was mostly made up of actors with the developmentalist rationality in the incumbent position, whose rules favored the implementation of the enterprise. The change in that scenario was triggered by the beginning of the first environmental assessment administrative process, when other rationalities began to compete in the field.

Therefore, MOAB has demonstrated its ability to mobilize and engage local actors, who assumed the position of challengers in the field and shared the symbolic rationality, supported by the defense of the territory as a space of collective memory, and use and sharing of resources. One of the actors mobilized by MOAB, which played a key role in the environmental suspension when permits were issued by the IAP, and SEMA, was the MPF. After the filing power of the public class action process (ACP) initiated by MOAB, the MPF requested the annulment of the licenses due to the interstate character of the project.

On the second attempt that MOAB applied for the environmental permit with IBAMA, they assumed the characteristics associated with the skilled actor, described by the Theory of Strategic Fields of Action. Through the stories of local life, especially 
of the quilombola remnants, the group drew the attention of other actors, transforming them into supporters of the cause of local communities. In that onslaught, CBA had its environmental permit denied due to insufficient information in the EIA/RIMA.

During the last attempt for environmental permitting, a new skilled actor appeared, now on the part of the incumbent actors: the environmental consulting firm, which demonstrated the ability to move the actors in favor of obtaining the environmental license. The organization assumed the position of mediator between the entrepreneur and the environmental agency. However, the challengers had already achieved national visibility. In addition, the initiatives originated from the actions carried out by MOAB included researchers, socio-environmental organizations, the MPF, the MPSP and a large part of society, whose support was gained through information disseminated in a national network.

In three attempts at environmental permitting, the EIA/RIMA confirming the environmental feasibility of the project and the developmentalist rationality shared among the incumbent players in the field indicated that the UHE Tijuco Alto HPP would be granted. However, the context presented throughout this study made possible a broader analysis of the project, which considered the other rationalities without neglecting the undeniably important technical issues.

In conclusion, the environmental permit was denied for the decision-making process, which symbolic rationality shared among the local population and supported by the Public Prosecution Department was very involved and committed for the cause. This rationality was highlighted because of the strategic actions developed by MOAB together with other actors, strengthening the local history during the protests and demonstrations.

Environmental protection requires social participation to overcome the tensions of a modernity project based on purely economic development goals. The focus should be the strengthening of the democracy with more participation, in which governance actually operates (SOUSA-CAMILO; ALMEIDA, 2019). Furthermore, this study shows that, although there are flaws in the participatory process, it is the only way capable of modifying the inequalities crystallized in society.

\section{Acknowledgments}

The authors thank the people involved in the analyzed conflict, the reviewers of the article who contributed to the improvement of the analysis and the Coordination for the Improvement of Higher Education Personnel - Brazil (CAPES) for the financial support given to Amanda dos Santos Sousa, through the grant of studies (Funding Code 001).

\section{References}

ARAÚJO, F.M; ALVES, E. M.; DA CRUZ, M. P. Algumas reflexões em torno dos conceitos de campo e de habitus na obra de Pierre Bourdieu. Revista Eletrônica Perspectivas da Ciência e 
Tecnologia, Rio de Janeiro, v. 1, n. 1, p. 31-40, 2008.

BARDIN L. Análise de conteúdo. Lisboa: Edições 70; 1977.

BRASIL. Decreto $\mathbf{n}^{\circ}$ 96.746, de 21 de setembro de 1988. Outorga à CBA concessão para o aproveitamento da energia hidráulica de um trecho do Rio Ribeira do Iguape, no local denominado Tijuco Alto, nos Municípios de Cerro Azul e Adrianópolis, Estado do Paraná, e Ribeira, Estado de São Paulo. Diário Oficial da União, Brasília/DF, 22 set. 1988, Seção 1, p. 18375.

BRASIL. Lei 6.938, de 31 de agosto de 1981. Política Nacional do Meio Ambiente. Diário Oficial da União, Brasília/DF, 2 set. 1981, Seção 1, p. 16509.

BRASIL. Lei no $\mathbf{9}$ 9.433, de 8 de janeiro de 1997. Institui a Política Nacional de Recursos Hídricos, cria o Sistema Nacional de Gerenciamento de Recursos Hídricos. Diário Oficial da União, Brasília/DF, 9 jan. 1997, Seção 1, p. 470.

CANDIDO, S. E. A. et al. Campos nos estudos organizacionais: iabordagens relacionais? Gestão \& Produção, São Carlos, v. 25, n. 1, p. 68-80, 2018.

CBA. Companhia Brasileira de Alumínio. Relatório de Impacto Ambiental - RIMA: Usina Hidrelétrica de Tijuco Alto, 2005. Disponível em: http://icenciamento.ibama.gov.br/Hidreletricas/ Tijuco\%20Alto/RIMA.pdf. Acesso em: 20 jul. 2020.

CONAMA. Resolução 009, de 03 de dezembro de 1987. Diário Oficial da União, Brasília/DF, 05 jun. 1990, Seção I, p. 12.945.

DA SILVA SOITO, J. O. L.; FREITAS, M. A. V. Amazon and the expansion of hydropower in Brazil: vulnerability, impacts and possibilities for adaptation to global climate change. Renewable and Sustainable Energy Reviews, v. 15, n. 6, p. 3165-3177, 2011.

DUFLO, E.; PANDE, R. Dams. The Quarterly Journal of Economics, v. 122, n. 2, p. 601-646, 2007.

FEARNSIDE, P. M. Hidrelétricas na Amazônia: impactos ambientais e sociais na tomada de decisões sobre grandes obras. Manaus: Editora do INPA, 2019.

FLIGSTEIN, N. The architecture of markets: an economic sociology of twenty-first-century capitalist societies. New Jersey: Princeton University Press, 2001.

FLIGSTEIN, N.; MCADAM, D. A theory of fields. Oxford: Oxford University Press, 2012.

GALVANESE, C.; FAVARETO, A. Dilemas do planejamento regional e as Instituições do Desenvolvimento sustentável. Revista Brasileira de Ciências Sociais, v. 84, n. 29, p. 73-84, 2014.

GALVÃO, J.; BERMANN, C. Crise hídrica e energia: conflitos no uso múltiplo das águas. Estudos avançados, v. 29, n. 84, p. 43-68, 2015.

GODOY, A. M. G. Teoria dos campos e políticas ambientais locais. Desenvolvimento e Meio 
ambientes, v. 24, p. 119-136, 2011.

HERNANDEZ, F. D. M. et al. Hydropower In The Amazon: Renewability And Non-renewability Of Energy Policy. Since Is Desired The Search For Renewable Energy Conversion Why Not Renew The Energy Policy As Well?. Boletim do Museu Paraense Emilio Goeldi: Ciências Humanas, v. 7, n. 3, p. 791-811, 2012.

IBAMA. Processo de Licenciamento Ambiental da UHE de Tijuco Alto no 2001.001172/200458. XXX Volumes, 2007-2016.

IBGE - INSTITUTO BRASILEIRO DE GEOGRAFIA E ESTATÍSTICA. Cidades. Disponível em: https://cidades.ibge.gov.br/. Acesso em: 5 fev. 2019.

INSTITUTO SOCIOAMBIENTAL. Barragens projetadas para o Rio Ribeira de Iguape. Instituto Socioambiental, 2007.Disponível em: https://www.socioambiental.org/. Acesso em: 20 jul. 2020.

JERONYMO, A. C. J.; BERMANN, C.; GUERRA, S. MG. Deslocamentos, itinerários e destinos de populações atingidas por Barragens: UHE Tijuco Alto, SP-PR. Desenvolvimento e meio ambiente, v. 25, 2012.

LEMOS, C. F. O Rio Ribeira do Iguape continua correndo livre: quinze anos de lutas contra a barragem de tijuco alto. In: ENCONTRO CIÊNCIAS SOCIAIS E BARRAGENS, 1., 2005, Rio de Janeiro. Anais [...]. Rio de Janeiro: UFRJ, 2005. Disponível em: http://www.ecsb2007.ufba.br/ layout/padrao/azul/ecsb2007/arquivos_anteriores/st2_03.pdf. Acesso em: 20 jul. 2020.

MACHADO-DA-SILVA, C. L.; GUARIDO FILHO, E. R.; ROSSONI, L. Campos organizacionais e estruturação: reflexões e possibilidade analíticas. Revista de Administração Contemporânea, v. 10, p. 159-196, 2006.

MIRANDA, D. L. R.; GOMES, B. M. A. Programas Nacional de Fortalecimento da Agricultura Familiar: trajetórias e desafios no Vale do Ribeira. Brasil. Soc. nat., v. 28, n. 3, p. 397-408, 2016.

MORAN, E. F. et al. Sustainable hydropower in the 21st century. Proceedings of the National Academy of Sciences, v. 115, n. 47, p. 11891-11898, 2018.

OLIVEIRA, C. E.; PAVANELLI, J. M. M., IGARI, A. T. Serviços ecossistêmicos e bens comuns: uma breve conceitualização. Diálogos Socioambientais Na Macrometrópole Paulista, v. 3, n. 07, p. 24-26, 2020.

PAVANELLI, J. M. M.; IGARI, A. T. Institutional Reproduction and Change: An Analytical Framework for Brazilian Electricity Generation Choices. International Journal of Energy Economics and Policy, v. 9, n. 5, p. 252, 2019.

PIAGENTINI, P. M.; BENASSI, R. F.; PENTEADO, C. L. C. Olhares sobre a hidreletricidade e o processo de licenciamento no Brasil. Estudos Avançados, v. 28, n. 82, p. 139-153, 2014.

PULICE, S. M. P. et al. Evaluating monetary-based benefit-sharing as a mechanism to improve lo- 
cal human development and its importance for impact assessment of hydropower plants in Brazil. Journal of Environmental Assessment Policy and Management, v. 21, n. 01, p. 1950003, 2019.

PUliCE, S. M. P.; MORETTO, E. M. A compensação Financeira e o Desenvolvimento dos Municípios Brasileiros Alagados por Usinas Hidrelétricas. Ambiente $\mathbb{\&}$ Sociedade, v. 20, n. 4, p. 103-126, 2017.

ROQUETTI, D. R.; MORETTO, E. M.; PULICE, S. M. P. Dam-forced displacement and socialecological resilience: The Barra Grande hydropower plant in Southern Brazil. Ambiente $\mathbb{\&}$ Sociedade, v. 20, n. 3, p. 115-134, 2017.

ROUGEMONT, L. S.; GÓMEZ, J. R. Usina Hidrelétrica de Tijuco Alto (vale do Ribeira) no contexto dos conflitos gerados pela construção de barragens. Revista Pegada, v. 12, n. 2, p. 48 59, 2011.

SOUSA-CAMILO, A. S.; ALMEIDA, P. S. Proteção da biodiversidade ambiental e cultural latino-americana: o caso da participação social na avaliação de impacto ambiental nos países do Mercosul. In: PEREIRA, W. P.; LUGO, C. (Org.). Democracia, Liderança e Cidadania na América Latina. São Paulo: Editora da Universidade de São Paulo, 2019. p. 393-412.

SOUZA, A. N.; JACOBI, P. R. Licenciamento ambiental e ampliação da cidadania: o caso da hidrelétrica de Tijuco Alto. Organizações \& Sociedade, v. 18, n. 57, p. 245-263, 2011.

ZHOURI, A. Justiça Ambiental, Diversidade Cultural e Accountability. Desafios para governança ambiental. Revista Brasileira de Ciências Sociais, v. 23, n. 68, p 97-194. 2008.

ZHOURI, A. Megaprojects, epistemological violence and environmental conflicts in Brazil. Revista Perfiles Económicos, n. 5, 2018. 
Amanda dos Santos Sousa

$\varangle$ contato.assousa@gmail.com

ORCiD: https://orcid.org/0000-0002-6404-2985
Submitted on: 12/09/2019

Accepted on: 11/08/2021

2021;24e:01623

\section{Paulo Santos de Almeida}

$\varangle$ psalmeida@usp.br

ORCiD: https://orcid.org/0000-0003-3240-4037

How to cite: SOUSA, A. S.; ALMEIDA, P. S. Environmental Assessment of the UHE Tijuco Alto Hydropower Plant: the change of the dominant order. Ambiente $\&$ Sociedade. São Paulo, v. 24, p. 1-20, 2021. 


\title{
Licenciamento Ambiental da Usina Hidrelétrica de Tijuco Alto: a mudança da ordem dominante
}

\author{
Amanda dos Santos Sousa \\ Paulo Santos de Almeida
}

São Paulo. Vol. 24, 2021

Artigo Original
Resumo: O objetivo desta pesquisa foi identificar, por meio da Teoria dos Campos de Ação Estratégica, as racionalidades abarcadas no licenciamento ambiental da hidrelétrica de Tijuco Alto (Região do Vale do Ribeira, Brasil) e caracterizar as estratégias dos principais atores implicados no processo de tomada de decisão. Como metodologia, adotou-se a descrição interpretativa, com base na análise documental e de conteúdo do processo de licenciamento ambiental. A avaliação desses documentos possibilitou concluir que as ações estratégicas arquitetadas pelo ator hábil - nesse caso, o Movimento dos Ameaçados por Barragens do Vale do Ribeira - foram fundamentais no movimento de visibilidade da racionalidade compartilhada pelas comunidades locais. Esse fato contribuiu com a mudança da ordem dominante, que prioriza a lógica desenvolvimentista e resulta, muitas vezes, na liberação de projetos que afetam ou violam os direitos humanos.

Palavras-chave: Avaliação de Impacto Ambiental, Diversidade Biológica, Uso da terra.

Como citar: SOUSA, A .S.; ALMEIDA, P. S. Licenciamento Ambiental da Usina Hidrelétrica de Tijuco Alto: a mudança da ordem dominante. Ambiente \& Sociedade. São Paulo, v. 24, p. 1-20, 2021.

DOI: http://dx.doi.org/10.1590/1809-4422asoc20200162r3vu2021L5AO 


\title{
Licenciamiento ambiental de la central hidroeléctrica de Tijuco Alto: cambio del orden dominante
}

\author{
Amanda dos Santos Sousa \\ Paulo Santos de Almeida
}

São Paulo. Vol. 24, 2021

Artículo original
Resumen: El objetivo de esta investigación fue identificar, a través de la Teoría de Campos de Acción Estratégica, los fundamentos incluidos en el licenciamiento ambiental de la central hidroeléctrica de Tijuco Alto (Región Vale do Ribeira, Brasil) y caracterizar las estrategias de los principales actores involucrados en el proceso de toma de decisión. Como metodología se adoptó la descripción interpretativa, basada en el análisis documental y de contenido del proceso de licenciamiento ambiental. La evaluación de estos documentos permitió concluir que las acciones estratégicas ideadas por el actor calificado - en este caso, el Movimiento de Amenazados por Represas en el Vale do Ribeira - fueron fundamentales en el movimiento de visibilidad de la racionalidad compartida por las comunidades locales. Este hecho contribuyó al cambio en el orden dominante, que prioriza la lógica del desarrollo y muchas veces resulta en la liberación de proyectos que afectan o violan los derechos humanos.

Palabras-clave: Participación Social; Habilidad Social; Evaluación de Impacto Ambiental; Derecho ambiental; Gobierno de los recursos hídricos.

Como citar: SOUSA, A. S.; ALMEIDA, P. S. Licenciamiento ambiental de la central hidroeléctrica de Tijuco Alto: cambio del orden dominante. Ambiente \& Sociedade. São Paulo, v. 24, p. 1-20, 2021.

DOI: http://dx.doi.org/10.1590/1809-4422asoc20200162r3vu2021L5AO 